\title{
Micro Grid Energy Management using DE Algorithm with BDC theorem
}

\author{
Anil Kumar.P.G, P. Aruna Jeyanthy, D. Devaraj,
}

\begin{abstract}
D E$ algorithm and benders decomposition theorem of VMG is used to solving the large scale mixed integer programming problems. DE algorithm is implemented in Village area Micro grids. Village area micro grid and the required load is calculated regarding the sold out power or purchase power with the help of DE algorithm. Differential evolution algorithm is applied in the village area micro grid and measure the real power, reactive power of various power plants. . In this DE algorithm is implemented in village area micro grid and the survey period is two years. Final survey shows which month produce more power and sold out power in nearest city area electricity board, But in power shortage in village area micro grid, it purchase the power from nearest electricity board.DE algorithm determine the one month power survey and benders decomposition determine the individual value of the power plants. But the benders decomposition theorem is not accept the non linearity items. To overcome this problem BDCT and DEA is implemented in village area micro grid. This combination is used to maintain the drop out voltage of any power plants.
\end{abstract}

Keywords-Village area micro grid (VAMG), Village area energy resources (VAERs), Differential Evolution Algorithm (DEA ) Benders decomposition theorem (BDCT).

\section{INTRODUCTION}

The VAMG and VAERs are maintain the village power shortage. VAMG power and electricity power will sold out or purchase 2 years for our survey. BDCT is greatly implemented to maintain the advantage of restricted VAMG and Electricity board power systems and planning. In this BDCT is very helpful for production and transmission of power in VAMG .But hybrid system of DEA and BDCT maintain the linearity and non linearity input and output items. This paper maintain the two years power production of solar, wind and fuel cell of VAMG and mutual shairing of power in electricity board and VAMG. The DE algorithm is used to VAMG and getting the best output and this output connected to Electricity board.

Now due To power balancing problems, a village 1 area micro grid can not only affect the power balancing of Electricity board. But it affect the non linearity output power compensation of non-conventional energy sources in the village area micro grid. When the VAMG operates in parallel operation or synchronizing operation electricity board connection, it maintains the power shortage and village area development. In this DEA and BDCT cannot destroy the village or rural area development.

Revised Manuscript Received on December 05, 2019.

Anil Kumar .P.G, Assistant Professor, Electrical and Electronics Engineering, Kottayam Institute of Technology and science.

Prof. P. Aruna Jeyanthy, Faculty, Electrical and Electronics Engineering , Kalasalingam University.

Prof. D. Devaraj, Faculty, Electrical \& Electronics Engineering, Kalasalingam University.

\section{ENERGY MANAGEMENT MODELING}

\section{A. Battery Modelling}

In the battery modelling, nickel cadmium cells are used to store the supply in the rural area micro grid and utility grid for energy management purpose. In this battery ions are move from negative iron to positive iron during discharge and back when charging. The parameters of storage capacity are nearby $20 \mathrm{Ah}$, with a nominal voltage of 370-380, added to the output of o the converter to reduce the output voltage ripples.

In this parallel operation of RAMG and utility grid primary cells are not used and this primary cells are affect the current, voltage and power compensation.

The charge level of secondary cell is follows:

$$
\mathrm{Q}_{\mathrm{C}} \mathrm{S}_{\text {oc.min }} \leq \mathrm{Q}_{\mathrm{i}}(\mathrm{t}) \leq \mathrm{Q}_{\mathrm{C}} \mathrm{S}_{\mathrm{oc} \cdot \max } \text { ' }
$$

Where $\mathrm{Q}_{\mathrm{i}}(t)$ indicate the charging amount of the

Nickel cadmium battery in time $t ; \mathrm{Q}_{\mathrm{C}}$ indicate the amount of

Power; and $\mathrm{S}_{\mathrm{oc}}$, max indicate the maximum and minimum power of the nickel cadmium battery.

If the battery is charging with the help of battery charger and discharging depend upon the load, the charging or discharging power should be limited as follows:

$$
0 \leq \mathrm{P}_{\mathrm{t} \leq \mathrm{P}^{\mathrm{C}} \text {.max }}
$$

For correct power balancing of RAMG and utility grid of the energy system, it is needed to ensure from the three sources will satisfy at least the essential demand.

The power stored in battery at time $t$ is used, when the parallel operation of RAMG and utility grid is not sufficient to meet the demand. On the another way energy from RES meets the consumer needs. But battery contains some limits:

$$
\text { Amin }<\mathrm{B}(\mathrm{t})<\mathrm{Amax}
$$

Where A min, A max indicated in depth of the discharge and maximum capacity of the battery respectively.

Finally constraints on total energy sending or receiving the battery and the consumers, can be imposed

$\mathrm{Vmin}<\mathrm{v}(\mathrm{t})<\mathrm{Vmax}$

\section{B. Solar Cell Modelling}

Solar cell is a variable nature. Depend upon the radiation of sun light power production is maintained. Initialise the solar plant is used $24 \mathrm{Hrs}$. Main grid solar panel and new micro grid solar panel size must be same or approximately same for synchronization works. 


\section{Wind Plant Modelling}

Wind plant is a variable nature. Depending upon the speed of the wind, power production is maintained. Initialize the wind plant is $24 \mathrm{Hrs}$. The power of modern onshore wind turbine is excess of $3 \mathrm{MW}$.Individual wind turbine, which are connected to electrical power transmission network. Sitting a wind farm varies from one location to another. But there are some important matters for compensation of current, voltage, frequency and amplitude. The proposed dc micro grid is connected with a wind power generator through a voltage source converter (VSC), but in ac micro grid is connected in wind plant directly. In the wind energy system has significant influence on various static and dynamic characteristics; Synchronous generator is connected to wind turbine and selling more supply to main grid. The size of the new micro grid wind plant and main grid wind plant must be same for easy synchronization works.

\section{Fuel Cell Modelling}

Fuel cell is a constant one. In this fuel cell is worked in all times. The efficiency of fuel cell is lower, the power output high. The size of the new micro grid fuel cell and main grid fuel cell must be same for easy synchronization works. Capable of using natural gas ,renewable bio gas and hydrogen feed stocks, a fuel cell plant located at the micro grid is superior to conventional gas turbines facilities in that a 50MW capability. Within micro grid, fuel cell assets provide a continuous energy "buffer" or management capability to cover shortages resulting from the inherent diurnal variations of RES. The ultimate goal is to bring the strength of RES technologies to bear on development on developing the best micro grid possible.

\section{MG ARCHITECTURE CELL MODELLING}

Energy management problem is balanced with the help of village area micro grid. Combination of BDCT and DEA of micro grid analyze the prediction value of VAMG.. The range from village area micro grid is $500 \mathrm{KE}$ to $40 \mathrm{MW}$ or needed for our village power. It is connected to Electricity board control Grid connected mode. It is used to close the electricity or heat permitted to by close to proximity to generator to the user, thereby increasing the overall efficiency. The energy management problem prices to minimizing the village area micro grid social net cost; So the price of storage, RES generation and worst-case transaction price minus the utility of dispatch able loads, The power management problem of VAMG is given through the following expression.

$=\min \sum_{t=1}^{T}\left[\sum_{g=1}^{G}\left(P_{g t}^{E}+P_{g t}^{R}\right)+p_{t}^{R E S}+\sum_{d=1}^{D} P d t\right.$

The storage and worst cost transaction is used to improve the efficiency and long term predictable energy cost. It reduces harmful emissions resulting from optimal use of renewable and energy efficiency programs. They are power disaster relief centres during regional and national crises. They are great for the environment. Because they use renewable resources and connected to main grid.

Main grid is controlled by Electricity board: The main grid is controlled by electricity board. An electrical energy management system an electrical energy generation system or power substation supervisory control and data acquisition systems (SCADA) systems often use electrical power management, especially those used in power plants. The transmission is controlled by OASIS. The power transmission of main grid is expressed in following expression

$$
=\min \sum_{t=1}^{T}\left[\sum_{g=1}^{G}\left(\begin{array}{c}
E \\
D g t
\end{array}+\begin{array}{c}
R \\
D g t
\end{array}\right)+{ }_{D t}^{R E S}+\sum_{d=1}^{D} D d t\right]
$$

(6)

Where,

$$
D_{g t}^{E}=a_{g} \cdot U{ }_{g t}+b_{g} \cdot P_{g t}+C_{g}^{\sup _{g}} \cdot Y_{g t}+C_{g}^{s d n} \cdot Z_{g t}
$$

(7)

(8)

$$
\begin{gathered}
R \\
D g t
\end{gathered}=\sum_{q \in Q} \sum_{k \in K} \stackrel{R}{R} \underset{g q k \cdot R}{c t}
$$

$$
{ }_{D t}^{R E S}=d w \cdot \sum_{w=1}^{W} \underset{w t}{f}+d v \cdot \sum_{v=1}^{v} \underset{P v t}{f}
$$

$$
\stackrel{D R}{D d t}=\sum_{n=1}^{N} d d n
$$

The advantage of evolutionary computation conceptual simplicity, broader-domain applications efficiency in solving real world problems, versatility incorporating domain knowledge, hybridization with conventional techniques, parallelism, robustness, self adoption and requirement of least human expertise.

\section{Objective Function Objective function includes} maximum power with low cost ,,dropout power, linearity, prediction value, purchased power and sold out power.DEA maintain which month village area micro grid power plants produce more power. Benders decomposition theorem identify the drop voltage of village area micro grid power plants and battery is ready to charge for self sufficient. So DEA maintain the $50 \%$ prediction value and BDCT maintain $50 \%$ prediction value. So the VAMG maintain $100 \%$ prediction value and the village getting better supply. Benders decomposition algorithm with Differential evolution algorithm:

By combining both BDCT with DEA integer problem and floating problems can be solved. In this combination of BDT and DEA linear problem and non linear problems can be solved. This operation is done very fast and convex to sub-problem can be minimized. There are three power plants are act as a non linear input. Non linear input is given to the DEA and getting better output. In this DEA is used to which month micro grid power plants are getting more power. This DEA output is given to the BDT and getting linear output. Every power 
plants has self-sufficient charge in every time of January to December months. BDCT is used to increased to fifty percentage of prediction value. Some times PV is dropout BDT identify the dropout voltage of PV and Battery charge for self sufficient .Sometimes wind power plants dropout, BDT identify the dropout voltage and Battery is charge for self sufficient. So BDCT increased the fifty percentage prediction value and DEA increased the fifty percentage prediction value.
Rural area micro grid purchasing and selling power is related to electricity utility grid and energy transaction. If the rural area micro grid with RES power is high as compared to load demand, it sell the power in electricity utility grid. Rural area micro grid power is less it bought the power the power in electricity utility grid. The real power, sold power and purchase power of solar, wind, fuel cell of two years survey is listed, be

Table 1. Total cost for 1-12 Months. (First year) Survey

\begin{tabular}{|c|c|c|c|c|c|c|c|c|c|c|c|c|}
\hline & January & February & March & April & May & June & July & August & September & October & November & $\mathbf{r}$ \\
\hline $\begin{array}{l}\text { Real power } \\
\text { of wind }(\mathrm{kw})\end{array}$ & 90.9811 & 90.6666 & 84.88888 & 73.5432 & 23 & 23.3 & 145.77 & 97.567 & 84.761 & 74 & 1.3 & $1 .$. \\
\hline $\begin{array}{ll}\text { Real } & \text { power } \\
& \\
\text { of } & \text { solar } \\
(\mathrm{kw}) & \\
\end{array}$ & 81.657 & 84.546 & 89.9876 & 90.9876 & 91.6543 & 43.876 & 54.652 & 76.987 & 45.876 & 45.87765 & 56.863 & $\begin{array}{l}25 \\
8 . \\
98 \\
65\end{array}$ \\
\hline $\begin{array}{l}\text { Real power } \\
\text { of fuel cell } \\
(\mathrm{kw})\end{array}$ & 145.987 & 145.435 & 1145.765 & 145.765 & 145.234 & 145.347 & 145 & 145 & 145.98 & 145 & 144.9999 & $\begin{array}{c}14 \\
5\end{array}$ \\
\hline $\begin{array}{l}\text { sold } \\
\text { power(kw) }\end{array}$ & 0 & 0 & 0 & 0 & 18.4919 & 28.3906 & $6.11 \mathrm{E}-05$ & $8.41 \mathrm{E}-05$ & 260.3 & $4.32 \mathrm{E}-02$ & 85.2912 & $\begin{array}{l}81 \\
.3 \\
9\end{array}$ \\
\hline $\begin{array}{l}\text { sold } \\
\operatorname{cost}(1 / \mathrm{h})\end{array}$ & 1 & 1 & 1 & 1.1 & 24.42 & 36.76 & $4.87 \mathrm{E}-04$ & $4.7651 \mathrm{E}-08$ & $5.8762 \mathrm{E}-06$ & $6,765 \mathrm{E}-08$ & 10.876 & $\begin{array}{l}91 \\
7 \\
65\end{array}$ \\
\hline $\begin{array}{l}\text { purchase } \\
\text { power }(\mathrm{kw}\end{array}$ & \begin{tabular}{|l|}
$2.876547 \mathrm{E}$ \\
$22-$
\end{tabular} & $4.76 \mathrm{E}-2 \mathrm{E}$ & $5.987 \mathrm{E}+22$ & 3.5643 & 2 & 2 & 2 & 2 & $6.8761 \mathrm{E}-89$ & 1 & 1 & 1 \\
\hline $\begin{array}{l}\text { purchase } \\
\text { cost }(1 / h)\end{array}$ & $\begin{array}{c}6,876 \mathrm{E} . \\
65\end{array}$ & $6.987 \mathrm{E}-33$ & 7.986E-76 & $9.654 \mathrm{E}-72$ & 2.1 & 2,1 & 12.1 & 2.1 & 2.1 & 2.2 & 2.2 .4 & $\begin{array}{l}2 . \\
34\end{array}$ \\
\hline $\begin{array}{l}\text { Total } \\
\operatorname{cost}(1 / \mathrm{h})\end{array}$ & 3 & 4 & 36.75 & 97.654 & 48.64 & .45 .345 & 82.64 & 86.947 & 87.654 & 90.876 & 00.987 & $\begin{array}{l}56 \\
9 \\
87\end{array}$ \\
\hline
\end{tabular}

Table II. Total cost for 1-12 Months (Second year) -Survey

\begin{tabular}{|c|c|c|c|c|c|c|c|c|c|c|c|c|}
\hline & January & February & march & April & May & June & July & August & September & October & November & December \\
\hline $\begin{array}{l}\text { Real } \\
\text { power of } \\
\text { wind } \\
(\mathrm{kw})\end{array}$ & 3 & $4 . .3$ & 4.5 & 401.432 & 511.87 & 510.342 & 461.9167 & 108.987 & 66.876 & 398.90 & 200.98 & 300.987 \\
\hline $\begin{array}{l}\text { Real } \\
\text { power of } \\
\text { solar } \\
(\mathrm{kw})\end{array}$ & 308.987 & 312.876 & 345.987 & 500.876 & 567.9876 & 98.8765 & 89.98776 & 76.8765 & 67.9876 & 65.9876 & 56.987 & 89.0987 \\
\hline $\begin{array}{l}\text { Real } \\
\text { power of } \\
\text { fuel cell } \\
(\mathrm{kw})\end{array}$ & 450 & 450 & 450 & 450 & 450.98 & 450 & 450 & 450 & 450 & 450 & 450 & 450 \\
\hline
\end{tabular}


Micro Grid Energy Management using DE Algorithm with BDC theorem

\begin{tabular}{|c|c|c|c|c|c|c|c|c|c|c|c|c|}
\hline $\begin{array}{l}\text { sold } \\
\text { power } \\
(\mathrm{kw}) \\
\end{array}$ & 111 & 167 & 218 & 453 & 543 & 421.111 & 321.65 & 213.86 & 200.765 & 118.987 & 69.8765 & 54.9876 \\
\hline $\begin{array}{l}\text { sold } \\
\operatorname{cost}(1 / \mathrm{h}) \\
\end{array}$ & 45.5432 & 60.99987 & 112,8765 & 233.654 & 543.23456 & 234.765 & 211.765 & 167.9876 & $\begin{array}{c}145.8765 \\
1 \\
\end{array}$ & 123,6543 & 101.876 & 101.987 \\
\hline $\begin{array}{l}\text { purchase } \\
\text { power } \\
(\mathrm{kw}\end{array}$ & $12.222 \mathrm{E}$ & $2.2222 \mathrm{E}$ & $3.543 \mathrm{E}$ & 0.8 & 0 & 0 & $\begin{array}{r}23.098 \\
6\end{array}$ & 40.765 & $\begin{array}{c}2.92 \mathrm{E}+0 \\
2\end{array}$ & 45.98 & 46.987 & 43.8765 \\
\hline $\begin{array}{l}\text { purchase } \\
\text { cost } \\
(1 / \mathrm{h})\end{array}$ & $2.222 \mathrm{E}$ & 3.333E1 & $1.1111 \mathrm{E}$ & $0.1111 \mathrm{E}$ & 0 & 0 & $7.765 \mathrm{E}$ & $6.987 \mathrm{E}$ & $8.876 \mathrm{E}$ & $5.876 \mathrm{E}$ & $5.9876 \mathrm{E}$ & 7.9876E- \\
\hline $\begin{array}{l}\text { Total } \\
\operatorname{cost}(1 / \mathrm{h})\end{array}$ & 45.76 & 76.98 & 23.98 & 52.987 & 106.453 & 69.2479 & 123.8765 & 94.4704 & 121.9876 & 142.9876 & 154.876 & 76.98776 \\
\hline
\end{tabular}

Fig (1) Sold cost survey plot of two years

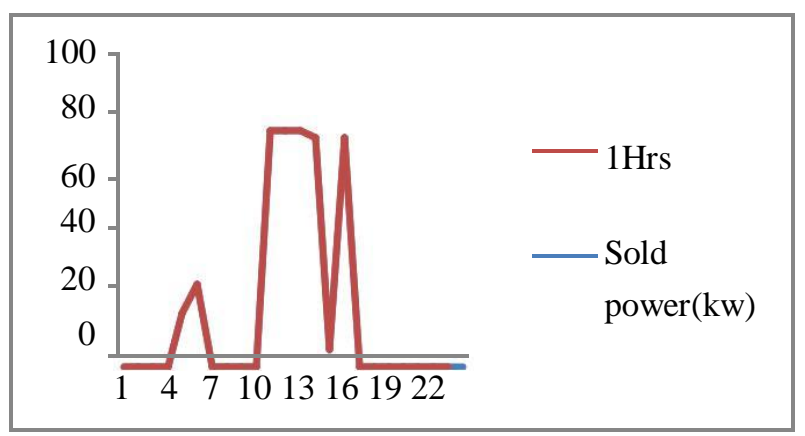

Fig (2) Total cost survey of two years

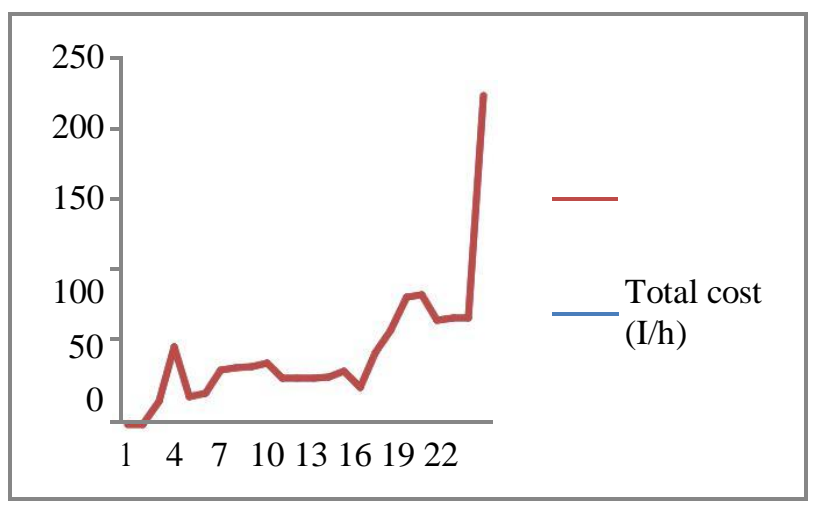

\section{CONCLUSION}

If the purchase power (or) load demand is high, village area micro grid bought needed supply from electricity board. Meanwhile if the need of power (or) load demand is low village area micro grid sold out the power in electricity. Energy transfer between electricity and village area micro grid is economical. Synchronizing of electricity board and village area micro grid increases overall efficiency. Differential evolution algorithm is used for surveying which month village area micro grid produce more power and maintain the energy management programme. In this survey second year may to September months power production is high. BDCT maintain the indivual power plant power and DEA
Fig (3) Purchase cost survey of two years

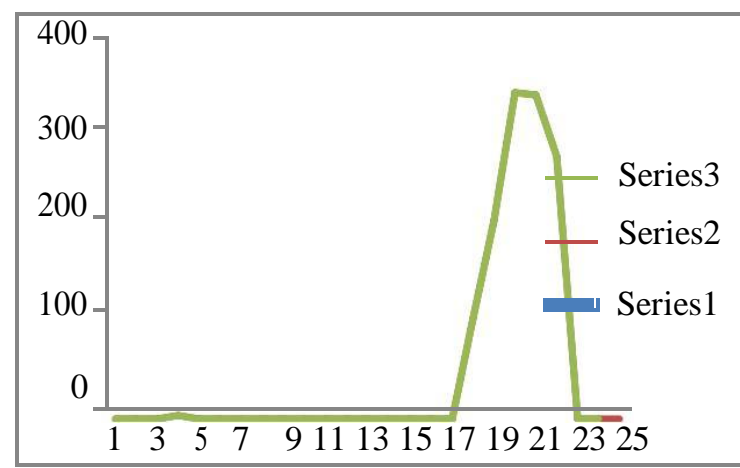

Fig (4) Overview of Electricity board with sub stations and Village area micro grid

Micro grid E.B

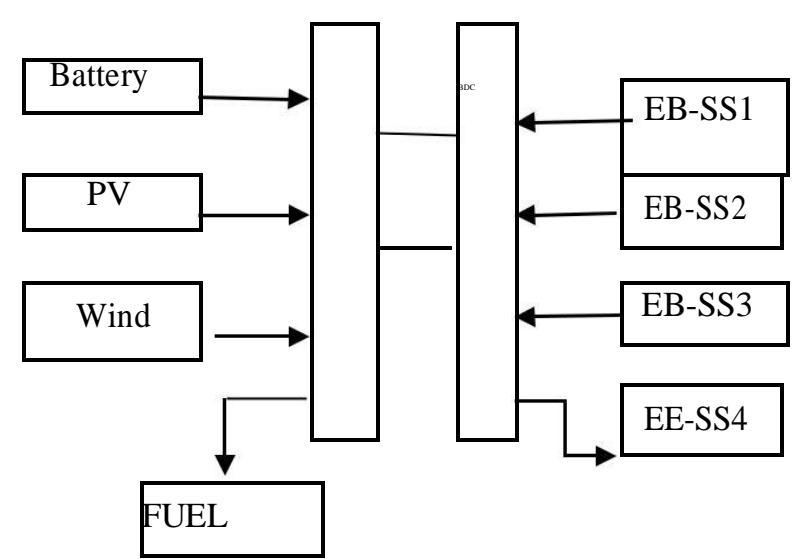

maintain the two year power production and combination maintain the linearity. In this combination maintain the hundred percentage prediction value. So overall efficiency is not affected.

\section{REFERENCES}

1. M. Yuyang, L. Jinling, and Z. Guodong, "Improved multiobjective particle optimization algorithm based scheduling optimization of grid connected micro grid," Elect. Power Sci. Eng., vol. 28, no. 7, pp. 15-20, 2012.

2. R. H. Liang and J. H. Liao, "A fuzzy-optimization approach for generation scheduling with wind and solar energy systems," IEEE Trans.Power Syst., vol. 22, no. 4, pp. 1665-1674, Nov. 2007.

3. N. Augustine, S. Suresh, P. Moghe, and K. Sheikh, "Economic dispatch for a microgrid considering 
renewable energy cost functions," in Proc.IEEE PES Innov. Smart Grid Technol. (ISGT), Washington, DC, USA, Jan. 2012, pp. 1-7.

4. M. Hemmai,N . Amjady and M Ehasan, "System modeling and optimization for islanded microgrid using multi-cross learning based chaotic differential Evolution

5. Algorithm”. Int.J. Electric power Energy system vol.56,340-360, nov 2013.

6. Alessandra Parisio, Evangelos Rikos, George Tzamalis and Luigi Glielmo, "Use of model predictive control for experimental micro grid optimization"25 Nov 2013

7. Alessandra Parisio, Evangelos Rikos, Luigi Glielmo,'

8. Stochastic model predictive control for economic / environmental operation management of micro grids. An experimental case study"13 may 2016.

9. S.Surender Reddy, Jae Young PARK, Chan Mook

10. JUNG, "Optimal operation of micro grid using hybrid differential evolution and harmony search algorithm"

11. Levron, Yoash, Guerrero, Joseph M Beck, Yuval,

12. "Optimal power flow in micro grids with Energy storage".

13. Nima Nikmehr and Sajad Najafi Ravadanegh, "Optimal power dispatch of Multi-Micro grids at Future Smart Distribution Grid.

14. IEEE Conferance on Control applications (CCA)Lonela Prodan and Enrico Zio "On the micro grid energy management under apredictive control frame work".

15. IEEE transations on power systems 2013, Levron, Yoash, Gurerrero, Joseph M, Beck, Yuval'Optimal power floe in micro grids with energy storage".

16. IEEE transations on neural network and learning systems, Ganesh kumar, Ratnesh k Sharma, prajwal and Afshin Ahmadi "DynamicEnergy Management System for a smart micro grid"

\section{AUTHORS PROFILE}

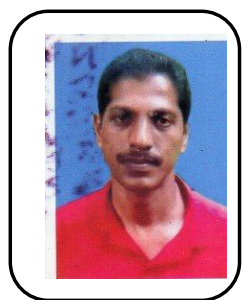

Anil Kumar .P.G Completed B-tech in Electrical and Electronics engineering in 2005 from Anna University., and ME in 2013 Power systems from Anna University. I am working as assistant professor in Kottayam Institute of Technology and science 2013 .Currently pursing $\mathrm{PhD}$ In Energy management in microgrid at Kalasalingam University Tamil Nadu.

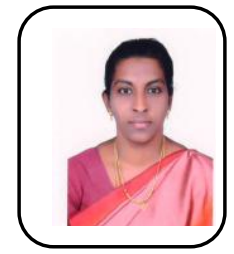

Prof. P. Aruna Jeyanthy Completed B.E in Electrical and Electronics Engineering from Madurai Kamaraj University and M.E in power systems from Annamalai University, also completed $\mathrm{Ph} . \mathrm{D}$ in electrical engineering on Evolutionary Algorithm-based Techniques for Voltage Security Enhancement from Anna University. currently works as the Faculty of Electrical and Electronics Engineering, Kalasalingam University. She has organized various Conferences, Seminars and conducted many workshops. She has chaired various technical sessions in many National and International Conferences. She has published papers in 29 international journals and 8 national journals. She has received many number of awards, Prizes and Honors for paper presentations and her valuable services in this field.

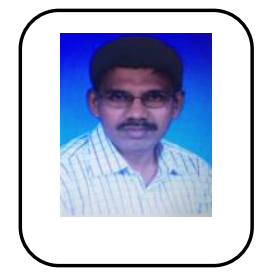

Prof. D. Devaraj Completed B.E and M.E in Electrical \& Electronics Engineering and Power System Engineering in the year 1992 and 1994, respectively, from Thiagarajar College of Engineering, Madurai. From 1994 to 1997, he worked as a Lecturer in Arulmigu Kalasalingam College of Engineering, Krishnankoil. He obtained his Ph.D degree from IIT Madras, Chennai in the year 2001. Since 2001, he is working as a faculty in the Electrical \& Electronics Engineering department of Kalasalingam University. He has organized 6 Conferences, 8 Seminars and conducted 10 workshops. He has published 105 papers in Journals and presented 250 papers in conferences. He has chaired 15 technical sessions in various National and International Conferences. He has Supervised 15 Ph.D, 2 M.S and 25 M.E thesis. Presently, he is guiding 8 Ph.D scholars. His research interest includes Power system security, Voltage stability, Smart grid, Evolutionary algorithms, Neural network and Data Mining. He is a senior member IEEE. Presently, he is the Dean - Academic, Senior Professor/EEE at Kalasalingam University, Krishnankoil 